\title{
An Atlantic streamer in stratospheric ozone observations and SD-WACCM simulation data
}

\author{
Klemens Hocke $^{1,2}$, Franziska Schranz $^{1}$, Eliane Maillard Barras ${ }^{3}$, Lorena Moreira $^{1,2}$, and Niklaus Kämpfer ${ }^{1,2}$ \\ ${ }^{1}$ Institute of Applied Physics, University of Bern, Bern, Switzerland \\ ${ }^{2}$ Oeschger Centre for Climate Change Research, University of Bern, Bern, Switzerland \\ ${ }^{3}$ Federal Office of Meteorology and Climatology, MeteoSwiss, Payerne, Switzerland \\ Correspondence to: Klemens Hocke (klemens.hocke@iap.unibe.ch)
}

Received: 9 November 2016 - Discussion started: 30 November 2016

Revised: 15 February 2017 - Accepted: 28 February 2017 - Published: 10 March 2017

\begin{abstract}
Observation and simulation of individual ozone streamers are important for the description and understanding of non-linear transport processes in the middle atmosphere. A sudden increase in mid-stratospheric ozone occurred above central Europe on 4 December 2015. The GROund-based Millimeter-wave Ozone Spectrometer (GROMOS) and the Stratospheric Ozone MOnitoring RAdiometer (SOMORA) in Switzerland measured an ozone enhancement of about $30 \%$ at $34 \mathrm{~km}$ altitude $(8.3 \mathrm{hPa})$ from 1 to 4 December. A similar ozone increase is simulated by the Specified Dynamics Whole Atmosphere Community Climate (SD-WACCM) model. Further, the global ozone fields at $34 \mathrm{~km}$ altitude $(8.3 \mathrm{hPa})$ from SD-WACCM and the satellite experiment Aura/MLS show a remarkable agreement for the location and timing of an ozone streamer (large-scale tongue-like structure) extending from the subtropics in northern America over the Atlantic to central Europe. This agreement indicates that SD-WACCM can inform us about the wind inside the Atlantic ozone streamer. SD-WACCM shows an eastward wind of about $100 \mathrm{~m} \mathrm{~s}^{-1}$ inside the Atlantic streamer in the mid-stratosphere. SD-WACCM shows that the Atlantic streamer flows along the edge of the polar vortex. The Atlantic streamer turns southward at an erosion region of the polar vortex located above the Caspian Sea. The spatial distribution of stratospheric water vapour indicates a filament outgoing from this erosion region. The Atlantic streamer, the polar vortex erosion region and the water vapour filament belong to the process of planetary wave breaking in the socalled surf zone of the northern midlatitude winter stratosphere.
\end{abstract}

\section{Introduction}

Rossby wave breaking contributes to the mean meridional circulation and to the horizontal mixing of tropical, subtropical and extratropical air masses in the middle atmosphere (Waugh, 1996; Randel et al., 1993; Leovy et al., 1985). Rossby wave breaking occurs in the middle and upper stratosphere during the winter season. In particular, the midlatitudes are regarded as the surf zone of the stratosphere where the material erosion of the polar vortex takes place (McIntyre and Palmer, 1984). The material erosion of the vortex leads to water vapour filaments at midlatitudes since the vortex air is rich in water vapour which has a long lifetime in the stratosphere. Müller et al. (2003) utilized simulation and observation data of stratospheric water vapour as a tracer for vortex filamentation in the Arctic winter.

Strong planetary waves shift the stratospheric polar vortex equatorwards, and subtropical air is drawn in tongue-like structures (streamers) from the subtropics to the extratropics. Offermann et al. (1999) observed the formation of the socalled Atlantic streamer in the trace gases $\mathrm{N}_{2} \mathrm{O}$ and $\mathrm{HNO}_{3}$. Krüger et al. (2005) derived climatological features of stratospheric streamers by means of the FUB-CMAM model with increased horizontal resolution $\left(2.8^{\circ} \times 2.8^{\circ}\right)$. They found that tropical-subtropical streamers mainly occur over the Atlantic and the east Asia/west Pacific region during Arctic winter. They emphasized that stratospheric streamers have nothing to do with ozone laminae (small-scale structures in vertical space) in the lower stratosphere. Khosrawi et al. (2005) reproduced the streamer distribution observed by the CRISTA experiment on board Space Shuttle (Offermann et al., 1999) with the Chemical Lagrangian Model of the Stratosphere 
(CLaMS) and the Karlsruhe Simulation Model of the Middle Atmosphere (KASIMA). These model-observation intercomparisons indicate that planetary wave breaking and induced stratospheric streamers are an excellent test for nonlinear wave-mean-flow interactions in middle atmospheric chemistry climate models.

In the following, we investigate whether the Specified Dynamics Whole Atmosphere Community Climate Model (SDWACCM) can simulate an individual Atlantic streamer event which was observed by the GROund-based Millimeter-wave Ozone Spectrometer (GROMOS) at Bern and the satellite experiment Aura Microwave Limb Sounder (Aura/MLS). Further, we look in detail on the role of the Atlantic streamer in the process of planetary wave breaking and polar vortex erosion.

\section{Data sets}

\subsection{The microwave radiometers GROMOS and SOMORA}

The study is partly based on stratospheric ozone profiles observed by GROMOS and the Stratospheric Ozone MOnitoring RAdiometer (SOMORA). The instruments are groundbased ozone microwave radiometers which are part of the Network for the Detection of Atmospheric Composition Change (NDACC). They continuously observe the middle atmosphere above Bern, Switzerland $\left(46.95^{\circ} \mathrm{N}, 7.44^{\circ} \mathrm{E}\right.$, $577 \mathrm{~m}$ above sea level) and Payerne, Switzerland $\left(46.82^{\circ} \mathrm{N}\right.$, $6.95^{\circ} \mathrm{E}, 471 \mathrm{ma}$ a.s.l.). While the routine observations of GROMOS started in 1994, SOMORA has been taking measurements since the year 2000. Both radiometers measure the thermal microwave emission of a rotational transition of ozone at $142.175 \mathrm{GHz}$. In our study, we use ozone profiles with an integration time of $2 \mathrm{~h}$ for GROMOS and $1 \mathrm{~h}$ for SOMORA. The hourly ozone profiles of SOMORA are averaged with a $3 \mathrm{~h}$ running mean in order to get close to the 2-hourly data of GROMOS and SD-WACCM. The valid altitude range of the ozone profiles is from 25 to $70 \mathrm{~km}$ with a vertical resolution of about $12 \mathrm{~km}$ in the stratosphere. The measurement response between 50 and $0.5 \mathrm{hPa}$ (20 to $52 \mathrm{~km}$ ) is higher than 0.8 (corresponding to a priori contributions less than $20 \%$ ). Therefore, the retrieved ozone values at these altitudes are primarily based on the measured line spectrum. For technical details, measurement principle and retrieval procedure of the instruments; see, for example, Moreira et al. (2015), Peter (1997), Hocke et al. (2007), Maillard Barras et al. $(2009,2015)$ and references included therein. An intercomparison study of Hocke et al. (2007) indicated that the relative differences between SOMORA and Aura/MLS are less than $10 \%$. Similar values of uncertainty are obtained for GROMOS. The SOMORA instrument is quite similar to GROMOS and was also upgraded with a FFT spectrometer in 2009. The vertical ozone profiles from
GROMOS and SOMORA have been validated by means of nearby ozone sondes, ground stations and collocated satellite measurements, the data sets have been used for studies of ozone-climate interaction, middle atmospheric dynamics as well as for long-term monitoring of the stratospheric ozone layer and for detection of trends (Moreira et al., 2015; Studer et al., 2014, 2012; Keckhut et al., 2010; Flury et al., 2009; Steinbrecht et al., 2009; Hocke et al., 2007; Dumitru et al., 2006).

\subsection{The Aura Microwave Limb Sounder}

The Microwave Limb Sounder is an instrument on board the NASA Aura satellite which was launched in July 2004. The level2 data of Aura/MLS consist of atmospheric vertical profiles with a spacing of $165 \mathrm{~km}\left(1.5^{\circ}\right.$ along the satellite orbit, which is sun-synchronous with an inclination of $98^{\circ}$ and a period of $98.8 \mathrm{~min}$ ) (Waters et al., 2006; Schwartz et al., 2008). This relatively dense, horizontal sampling should be sufficient for observing ozone streamers. The vertical resolution of the ozone profiles of Aura/MLS ranges from $3 \mathrm{~km}$ in the stratosphere to $6 \mathrm{~km}$ in the mesosphere (Schwartz et al., 2008). The present study utilizes Aura/MLS data of the version 4.2. The global ozone maps of Aura/MLS were computed by interpolating the valid ozone profiles of 1 day to a horizontal grid $\left(2^{\circ} \times 2^{\circ}\right)$ using a Delaunay triangulation (Matlab function TriScatteredInterp.m). The validity of the ozone or water vapour values from Aura/MLS is limited by uncertainty thresholds which are described in the data quality document for each species (Livesey et al., 2016).

\subsection{The SD-WACCM model}

The Specified Dynamics Whole Atmosphere Community Climate Model (SD-WACCM) was described and evaluated in detail by Brakebusch et al. (2013). Here, we use the Community Earth System Model (CESM) version 1.2.2 WACCM component set which is a coupled chemistry climate model of the National Center for Atmospheric Research (NCAR). The WACCM chemistry module is taken from the Model for OZone And Related chemical Tracers (MOZART) (Brasseur et al., 1998) but is extended to include 122 species (Lamarque et al., 2012). SD-WACCM is a modified version of WACCM in which the meteorology is constrained to match observations to within a user-defined tolerance (Lamarque et al., 2012; Kunz et al., 2011; Brakebusch et al., 2013). SDWACCM is nudged with winds, temperature, surface pressure, surface wind stress and heat fluxes from the Goddard Earth Observing System 5 (GEOS5) analysis (Rienecker et al., 2008). The nudging coefficient is in our study 0.1; i.e. the winds, temperature and surface pressure are defined by a linear combination of $10 \%$ from GEOS5 and $90 \%$ from the model. Nudging is applied every $30 \mathrm{~min}$. The model run was initialized on 1 July 2015 by means of a former WACCM run and GEOS5 data. The model output files are written ev- 

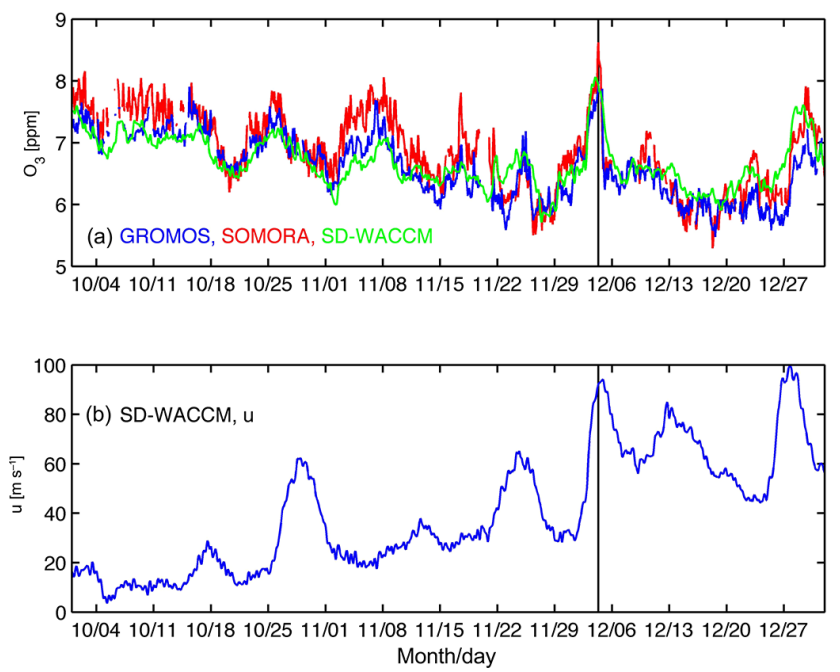

Figure 1. Time series of ozone volume mixing ratio and zonal wind at $34 \mathrm{~km}$ altitude above Bern, Switzerland from October to December 2015. The vertical red line is at 4 December 2015 12:00 UT when the ozone streamer reached Bern. (a) Time series of ozone observed by GROMOS (Bern) and SOMORA (Payerne) versus the simulated SD-WACCM ozone series at the grid point nearest to Bern. (b) Time series of eastward wind simulated by SD-WACCM at $34 \mathrm{~km}$ altitude.

ery $2 \mathrm{~h}$, the horizontal resolution is $1.9^{\circ} \times 2.5^{\circ}$ (latitude $\times$ longitude), and the vertical resolution is about $1 \mathrm{~km}$ in the stratosphere. The altitude range of SD-WACCM is from the surface to $140 \mathrm{~km}$ whereby nudging is only applied below $50 \mathrm{~km}$. In the present study, we work with SD-WACCM output data which have a time resolution of $2 \mathrm{~h}$. SD-WACCM can resolve planetary waves while short-term gravity waves are parameterized (Brasseur et al., 1998).

\section{Results}

The initial point of the present study was the occurrence of an ozone peak in mid-stratospheric ozone at Bern on 4 December 2015. Figure 1a shows the time series of ozone at $34 \mathrm{~km}$ altitude $(8.3 \mathrm{hPa})$ above Bern as observed by the GROMOS microwave radiometer at Bern and the SOMORA microwave radiometer at Payerne. Ozone suddenly increases by about $30 \%$ from 1 to 4 December. The time series of ozone from SD-WACCM is included in Fig. 1a. Generally the ozone time series of SD-WACCM is smoother than those of GROMOS and SOMORA. SD-WACCM reproduces the increase in ozone around 4 December 2015. The maximum in zonal wind of SD-WACCM (Fig. 1b) is at the time of the ozone peak observed by GROMOS (Fig. 1a). In summary, ozone-rich air passed above Bern with a velocity of about $90 \mathrm{~m} \mathrm{~s}^{-1}$ at $34 \mathrm{~km}$ altitude.

The next step is to derive the vertical ozone profiles of GROMOS, SD-WACCM, and Aura/MLS above or close to
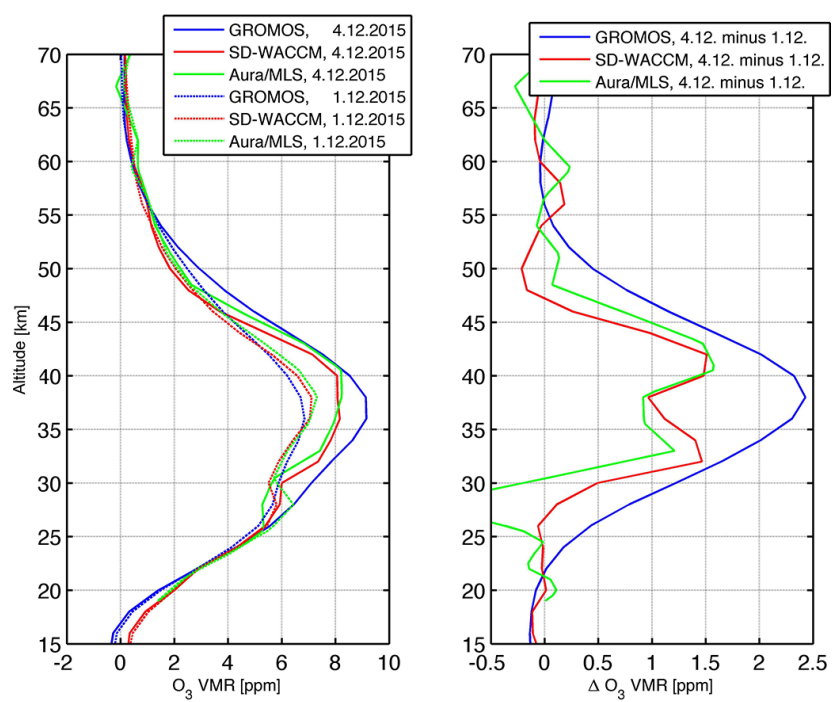

Figure 2. Left-hand side: vertical ozone profiles at Bern (or close to Bern) before the streamer arrival on 1 December 2015 12:00 UT (dashed line) and at the streamer arrival on 4 December 2015 12:00 UT. The GROMOS observations are indicated by the blue lines, the SD-WACCM results are given by the red lines, and Aura/MLS is shown by the green lines. Right-hand side: difference between the ozone profiles from 4 and 1 December 2015. The relative uncertainties of GROMOS, SOMORA and Aura/MLS are about $10 \%$.

Bern which are shown on the left-hand-side of Fig. 2 for 1 December 2015 (dashed lines) and 4 December 2015 (solid lines). Ozone reaches a maximum of $9 \mathrm{ppm}$ at $37 \mathrm{~km}$ altitude with GROMOS and a maximum of about $8 \mathrm{ppm}$ at the same altitude with SD-WACCM and Aura/MLS. The ozone increase takes place in the mid-stratosphere between 30 and $45 \mathrm{~km}$. This layer thickness of $15 \mathrm{~km}$ is given by the full width at half maximum of the ozone peaks of the difference profiles of SD-WACCM, Aura/MLS and GROMOS at the right-hand-side of Fig. 2. The double-peak structure in the difference profile of SD-WACCM is confirmed by the Aura/MLS observation. The vertical resolution of GROMOS $(12 \mathrm{~km})$ is not sufficient for resolving such a double peak. The profiles of Aura/MLS and SD-WACCM are not folded with the averaging kernels of GROMOS since we do not like to degrade the vertical resolution of the ozone profiles of Aura/MLS and SD-WACCM.

The formation and the decay of the Atlantic streamer is shown in Fig. 3a, b and $\mathrm{c}$ which show the global ozone field at $8.3 \mathrm{hPa}$ (ca. $34 \mathrm{~km}$ altitude) as simulated by $\mathrm{SD}$ WACCM for 1, 4 and 8 December 2015. We selected the polar stereographic projection in order to be in the same position as an observer in space who would be looking at the Earth. The Atlantic streamer starts with a tongue-like structure, stretching from Mexico over the Atlantic to Morocco. Later, on 4 December 2015, a narrow ozone streamer was formed from Mexico to central Europe. The ozone streamer is moved southward and fades away in Fig. 3c. The SD- 

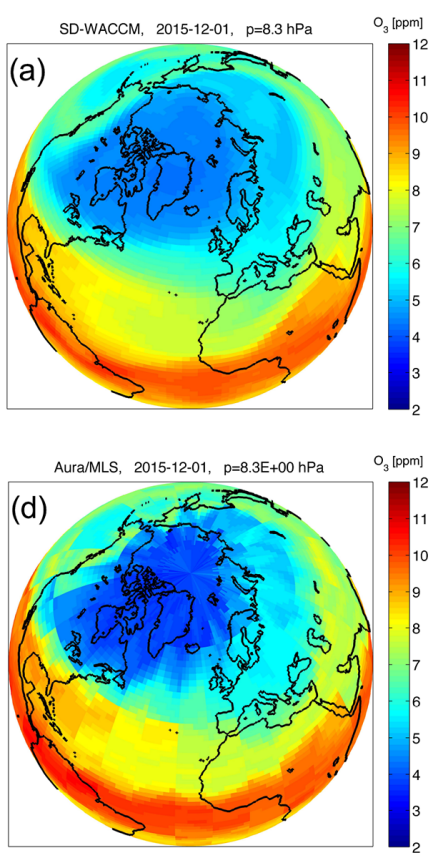
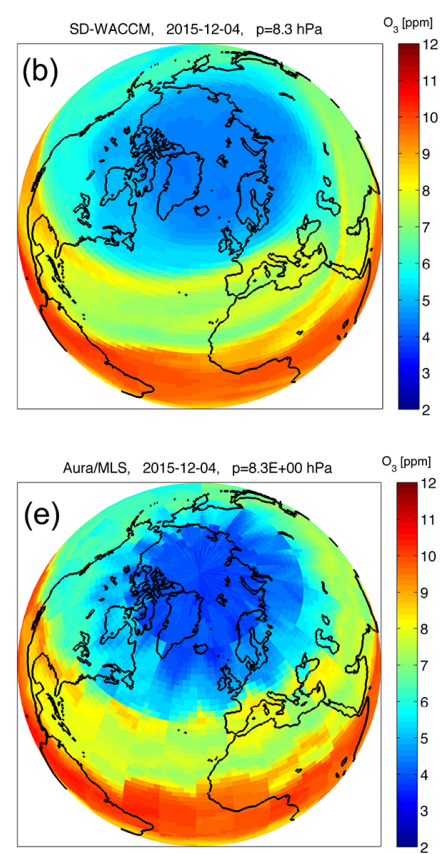
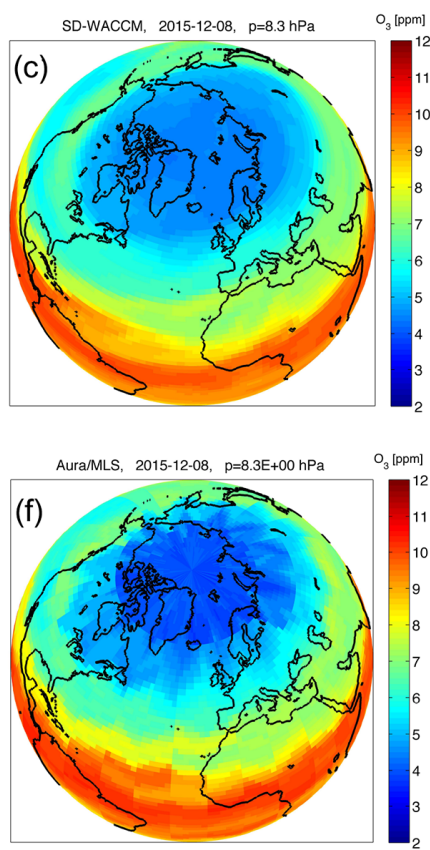

Figure 3. (a) Beginning of an ozone streamer extending from Mexico over the Atlantic to Morocco on 1 December 2015 at $8.3 \mathrm{hPa}$ (ca. $34 \mathrm{~km}$ altitude) and simulated by SD-WACCM. (b) The ozone streamer narrows and extends to central Europe on 4 December 2015 . (c) The ozone streamer is shifted southward and fades away on 8 December 2015. The graphs (d), (e) and (f) are based on all valid ozone profiles of Aura/MLS measured during the days 1, 4 and 8 December 2015.

WACCM simulation of the formation and the decay of the Atlantic streamer is confirmed by the Aura/MLS observations in Fig. 3d, e and f. Please note that the ozone field of Aura/MLS was not used for nudging the SD-WACCM model run. The structures of the Atlantic streamer in the pure Aura/MLS ozone fields are quite similar to those in the SDWACCM ozone fields. This is a confirmation of the nonlinear wave-mean-flow interactions in the stratosphere as simulated by SD-WACCM. Generally, the streamer is clearer in the SD-WACCM simulation than in the Aura/MLS observations. There are at least two reasons which may explain this result. The SD-WACCM model simulation does not resolve all inertia-gravity waves which may disturb the formation and duration of streamers and filaments. Secondly, the limited horizontal and temporal sampling of the Aura/MLS observations may render a clear detection of streamers and filaments.

Figure $4 \mathrm{a}$ shows the ozone distribution at $8.3 \mathrm{hPa}$ during a Rossby wave breaking process which can be recognized by the comma-shaped polar vortex with an outflow of ozonepoor air from the polar region to northern Africa. Figure $4 \mathrm{~b}$ zooms into the Atlantic streamer over Europe on 4 December 2015. The colour shading gives the ozone value and the arrows depict the horizontal wind vector. The largest arrows correspond to wind speeds of about $100 \mathrm{~m} \mathrm{~s}^{-1}$. The figure clearly shows that a narrow stream of ozone-rich air extends over the Atlantic to France, and it turns southward over eastern Europe.
Figure 5a utilizes water vapour as a tracer of polar vortex air and shows the spatial distribution of stratospheric water vapour at $8.3 \mathrm{hPa}$ on 4 December 2015. Small arrows indicate the horizontal wind. An erosion region of polar, water vapour-rich air appears above the Caspian Sea, ending in a long filament of water vapour pointing in a south-westerly direction. This finding is in a qualitative agreement with the vortex filamentation studies of Müller et al. (2003) and Koh and Legras (2002) and the Rossby wave breaking study of Polvani and Saravanan (2000). Comparison with Fig. 5a) shows that the Atlantic ozone streamer is located at the edge of the polar vortex. In addition the ozone streamer in Fig. 4a turns southward before reaching the vortex erosion region above the Caspian Sea. Figures 4a and 5a are appropriate for visualizing the surf zone of the midlatitude stratosphere in winter (McIntyre and Palmer, 1984). Figures 4a and 5a also show the anti-correlation of the spatial distributions of ozone and water vapour in the mid-stratosphere since stratospheric polar air is rich in water vapour and poor in ozone.

Finally, we like to compare the water vapour distribution of SD-WACCM (Fig. 5a) with the observations of the satellite experiment Aura/MLS on 4 December 2015. Figure $5 \mathrm{~b}$ shows the result of Aura/MLS at $8.3 \mathrm{hPa}$ which is close to $34 \mathrm{~km}$ altitude. The water vapour distributions of Aura/MLS and SD-WACCM are in a good agreement. The vortex erosion region over the Caspian Sea is unclear in the case of Aura/MLS. The water vapour filament over northern 

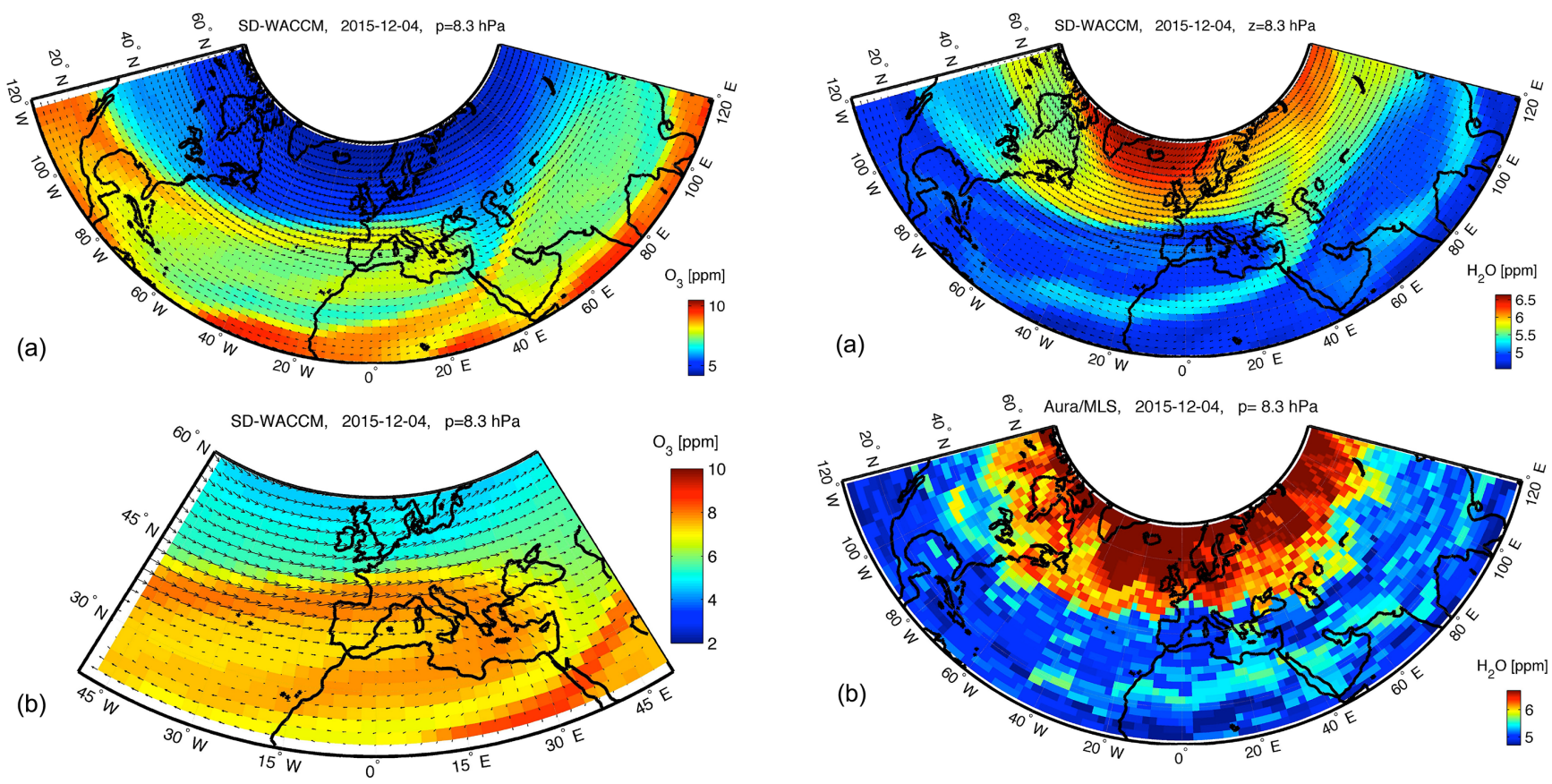

Figure 4. (a) Ozone distribution at $8.3 \mathrm{hPa}$ (ca. $34 \mathrm{~km}$ altitude) on 4 December 2015 based on the SD-WACCM simulation. The figure indicates the effects of a breaking Rossby wave in the polar wintertime stratosphere. (b) Zoomed-in image of (a): the Atlantic ozone streamer reaches central Europe and turns southward over eastern Europe. The largest arrows correspond to wind speeds of about 100 $\mathrm{m} \mathrm{s}^{-1}$ within the Atlantic streamer at $8.3 \mathrm{hPa}(34 \mathrm{~km})$.

Africa in Fig. $5 b$ indicates that there was a transport of watervapour-rich air from the polar vortex to the subtropics.

\section{Discussion}

Rossby waves propagate from the troposphere into the stratosphere during winter. They propagate along the polar vortex edge where the horizontal gradient of potential vorticity (PV) is maximal. The Rossby wave amplitude increases with height, and the Rossby wave can break in the midstratosphere. According to three-dimensional simulations of the Rossby wave breaking process by Polvani and Saravanan (2000) the process has a duration of 10-20 days. With zonal wave-number 1 forcing, wave breaking usually initiates a deep helical tongue of PV that is extruded from the polar vortex (Polvani and Saravanan, 2000).

Our SD-WACCM simulation of the water vapour distribution in Fig. 5a confirms the generation of a deep helical tongue of PV since water vapour is known as a good tracer of $\mathrm{PV}$ in the stratosphere. Figure 5a clearly shows the commashaped vortex erosion region which ends in a narrow water vapour filament over northern Africa. This filament is also present in the observations by Aura/MLS (Fig. 5b). However in the Aura/MLS observations the water vapour filament

Figure 5. Water vapour distribution at $8.3 \mathrm{hPa}(34 \mathrm{~km})$ on $4 \mathrm{De}-$ cember 2015 simulated by SD-WACCM. Water vapour is a tracer of polar vortex air. It indicates an erosion region of the polar vortex located above Caspian Sea. A comma-shaped, helical tongue of water vapour-rich air reaches northern Africa. The water vapour distribution is anti-correlated to the ozone distribution in Fig. 4a. (b) Water vapour distribution at $8.3 \mathrm{hPa}(34 \mathrm{~km})$ on 4 December 2015 observed by Aura/MLS. The water vapour filaments above northern Africa agree with the SD-WACCM simulation result in (a).

over northern Africa is not connected to the polar vortex. It remains open as to whether this is a substantial difference between the simulation and the observation since the spatiotemporal sampling of Aura/MLS is limited - particularly the sampling in longitude which is about $24^{\circ}$ while the sampling in latitude is about $1.5^{\circ}$. Thus, the vortex erosion region is a bit undersampled by Aura/MLS so that the vortex erosion and the filaments are clearer in the SD-WACCM simulation than in the Aura/MLS observations. Figure 5b does not change much if we reduce the time interval of the collected water vapour profiles from 24 to $12 \mathrm{~h}$, centred at 12:00 UTC. The limited temporal sampling of the Aura/MLS maps seems to not be critical.

On the other hand, a realistic representation/parameterization of gravity waves in climate models is quite challenging. A link between poleward-breaking Rossby waves in the upper troposphere and the generation of stratospheric inertia-gravity waves was shown by Zülicke and Peters (2008). Such links of waves across the scales could be a reason for a substantial deviation between the model and observation in the vortex erosion region. We suggest that, in reality, inertia-gravity waves which are not resolved or imperfectly parameterized in the model 
simulation may disturb the formation and duration of streamers, filaments and vortex erosion regions. Because of the importance of the Rossby wave breaking process for the circulation, dynamics and composition of the middle atmosphere, we think that further intercomparisons between the models and remote sensing observations are needed. In particular, the occurrence of streamers, filaments and vortex erosion regions should be intercompared in further observational and simulation studies. Atlantic streamers regularly occur in simulations such as in the statistical simulation study by Krüger et al. (2005). Satellite and ground-based observations indicate that the polar vortex edge is often shifted by a zonal wave-number 1 forcing towards the European longitude sector in wintertime. Thus, our selected case study is possibly representative for a major part of the Rossby wave breaking processes in the mid-stratosphere.

\section{Conclusions}

An Atlantic streamer was detected in stratospheric ozone observations of the space-based microwave radiometer Aura/MLS and the ground-based microwave radiometers GROMOS and SOMORA in Switzerland. These observations were compared to SD-WACCM simulation data. Generally, the simulations of SD-WACCM are realistic and agree with the observed ozone maps and ozone time series. The timing of the streamer event on 4 December 2015 and the global structure of the Atlantic streamer agree well for Aura/MLS, SD-WACCM, GROMOS and SOMORA. One can see the extension of the tongue-like structure which transports subtropical ozone-rich air from Mexico to central Europe. The Atlantic streamer is strongest at altitudes between 30 and $45 \mathrm{~km}$. Eastward wind speeds of about $100 \mathrm{~m} \mathrm{~s}^{-1}$ are reached inside the narrow streamer.

The SD-WACCM simulation of the spatial distributions of horizontal wind, water vapour and ozone in Figs. 4 and 5 show details of planetary wave breaking in the surf zone at $8.3 \mathrm{hPa}$ at northern midlatitudes on 4 December 2015. The Atlantic ozone streamer flows eastward at the edge of the polar vortex. The ozone streamer turns southward before reaching the Caspian Sea where a vortex erosion region is located. The vortex erosion region shows an increase of watervapour-rich polar air. A water vapour filament flows from this region in southwesterly direction. Generally, the spatial distributions of water vapour and ozone are anti-correlated so that the ozone streamer contains water-vapour-poor air and the water vapour filament contains ozone-poor air. The SDWACCM simulation shows that the Atlantic streamer is a part of the planetary wave breaking process in the surf zone of the midlatitude stratosphere in winter. This result is in agreement with Waugh (1996), who reported that transport out of the tropics occurs in Rossby wave breaking events in which streamers of tropical air are drawn into middle latitudes in the winter season. The streamers and filaments at
$8.3 \mathrm{hPa}(34 \mathrm{~km})$ are clearer in the SD-WACCM simulation than in the Aura/MLS observations. We suggest that in reality, inertia-gravity waves which are not resolved in the model simulation may disturb the formation and duration of streamers and filaments. Another reason is the limited longitude sampling of the Aura/MLS limb sounding observations since two subsequent orbits of Aura are spaced by about $24^{\circ}$ in longitude.

Code availability. Routines for data analysis and visualization are available upon request by Klemens Hocke.

Data availability. The ground-based ozone measurements of SOMORA and GROMOS are available in the data centre of the Network for the Detection of Atmospheric Composition Change (http://www.ndacc.org, NDACC, 2017). The Aura/MLS level2 data are available at the Aura Validation Data Center (http://avdc.gsfc. nasa.gov/, AVDC, 2017). The SD-WACCM simulation data of winter 2015/2016 are available by the author Franziska Schranz.

Author contributions. Franziska Schranz performed the SDWACCM model simulation. Klemens Hocke carried out the plots. Eliane Maillard Barras took care on the SOMORA data. All authors contributed to the interpretation of the data sets.

Competing interests. The authors declare that they have no conflict of interest.

Acknowledgements. We thank the Aura/MLS team and NASA/JPL for the microwave limb sounding measurements and the provision of the level2 data set at the Aura Validation Data Center (http://avdc.gsfc.nasa.gov/). We are grateful to the National Center for Atmospheric Research (Boulder) for providing the SD-WACCM model. The study was supported by the Swiss National Science Foundation under grant number 200020-160048 and 200021-165516.

Edited by: F. Khosrawi

Reviewed by: two anonymous referees

\section{References}

Aura Validation Data Center (AVDC): Level-2 data, available at: http://avdc.gsfc.nasa.gov/, last access: 1 February 2017.

Brakebusch, M., Randall, C. E., Kinnison, D. E., Tilmes, S., Santee, M. L., and Manney, G. L.: Evaluation of Whole Atmosphere Community Climate Model simulations of ozone during Arctic winter 2004/2005, J. Geophys. Res.-Atmos., 118, 2673-2688, doi:10.1002/jgrd.50226, 2013.

Brasseur, G. P., Hauglustaine, D. A., Walters, S., Rasch, P. J., Müller, J.-F., Granier, C., and Tie, X. X.: MOZART, a global 
chemical transport model for ozone and related chemical tracers: 1. Model description, J. Geophys. Res.-Atmos., 103, 2826528289, doi:10.1029/98JD02397, 1998.

Dumitru, M. C., Hocke, K., Kämpfer, N., and Calisesi, Y.: Comparison and validation studies related to ground-based microwave observations of ozone in the stratosphere and mesosphere, J. Atmos. Solar Terr. Phys., 68, 745-756, 2006.

Flury, T., Hocke, K., Haefele, A., Kämpfer, N., and Lehmann, R.: Ozone depletion, water vapor increase, and PSC generation at midlatitudes by the 2008 major stratospheric warming, J. Geophys. Res.-Atmos., 114, D18302, doi:10.1029/2009JD011940, 2009

Hocke, K., Kämpfer, N., Ruffieux, D., Froidevaux, L., Parrish, A., Boyd, I., von Clarmann, T., Steck, T., Timofeyev, Y. M., Polyakov, A. V., and Kyrölä, E.: Comparison and synergy of stratospheric ozone measurements by satellite limb sounders and the ground-based microwave radiometer SOMORA, Atmos. Chem. Phys., 7, 4117-4131, doi:10.5194/acp-7-4117-2007, 2007.

Keckhut, P., Hauchecorne, A., Blanot, L., Hocke, K., GodinBeekmann, S., Bertaux, J.-L., Barrot, G., Kyrölá, E., van Gijsel, J. A. E., and Pazmino, A.: Mid-latitude ozone monitoring with the GOMOS-ENVISAT experiment version 5: the noise issue, Atmos. Chem. Phys., 10, 11839-11849, doi:10.5194/acp10-11839-2010, 2010.

Khosrawi, F., Grooß, J.-U., Müller, R., Konopka, P., Kouker, W., Ruhnke, R., Reddmann, T., and Riese, M.: Intercomparison between Lagrangian and Eulerian simulations of the development of mid-latitude streamers as observed by CRISTA, Atmos. Chem. Phys., 5, 85-95, doi:10.5194/acp-5-85-2005, 2005.

Koh, T.-Y. and Legras, B.: Hyperbolic lines and the stratospheric polar vortex, Chaos, 12, 382-394, doi:10.1063/1.1480442, 2002.

Krüger, K., Langematz, U., Grenfell, J. L., and Labitzke, K.: Climatological features of stratospheric streamers in the FUB-CMAM with increased horizontal resolution, Atmos. Chem. Phys., 5, 547-562, doi:10.5194/acp-5-547-2005, 2005.

Kunz, A., Pan, L. L., Konopka, P., Kinnison, D. E., and Tilmes, S.: Chemical and dynamical discontinuity at the extratropical tropopause based on START08 and WACCM analyses, J. Geophys. Res.-Atmos., 116, D24302, doi:10.1029/2011JD016686, 2011.

Lamarque, J.-F., Emmons, L. K., Hess, P. G., Kinnison, D. E., Tilmes, S., Vitt, F., Heald, C. L., Holland, E. A., Lauritzen, P. H., Neu, J., Orlando, J. J., Rasch, P. J., and Tyndall, G. K.: CAM-chem: description and evaluation of interactive atmospheric chemistry in the Community Earth System Model, Geosci. Model Dev., 5, 369-411, doi:10.5194/gmd-5-369-2012, 2012.

Leovy, C. B., Sun, C.-R., Hitchman, M. H., Remsberg, E. E., Russell, III, J. M., Gordley, L. L., Gille, J. C., and Lyjak, L. V.: Transport of ozone in the middle stratosphere - Evidence for planetary wave breaking, J. Atmos. Sci., 42, 230-244, doi:10.1175/15200469(1985)042<0230:TOOITM>2.0.CO;2, 1985.

Livesey, N. J., Read, W. G., Wagner, P. A., Froidevaux, L., Lambert, A., Manney, G. L., Valle, L. F. M., Pumphrey, H. C., Santee, M. L., Schwartz, M. J., Wang, S., Fuller, R. A., Jarnot, R. F., Knosp, B. W., and Martinez, E.: EOS Aura-MLS Version 4.2x Level 2 data quality and description document, JPL D-33509 Rev. B, 1-164, 2016.
Maillard Barras, E., Ruffieux, D., and Hocke, K.: Stratospheric ozone profiles over Switzerland measured by SOMORA, ozonesonde and MLS/AURA satellite, Int. J. Remote Sens., 30, 4033-4041, 2009.

Maillard Barras, E., Haefele, A., Stübi, R., and Ruffieux, D.: A method to derive the Site Atmospheric State Best Estimate (SASBE) of ozone profiles from radiosonde and passive microwave data, Atmospheric Measurement Techniques Discussions, 8, 3399-3422, doi:10.5194/amtd-8-3399-2015, 2015.

McIntyre, M. E. and Palmer, T. N.: The 'surf zone' in the stratosphere, J. Atmos. Terr. Phys., 46, 825-849, doi:10.1016/00219169(84)90063-1, 1984.

Moreira, L., Hocke, K., Eckert, E., von Clarmann, T., and Kämpfer, N.: Trend analysis of the 20-year time series of stratospheric ozone profiles observed by the GROMOS microwave radiometer at Bern, Atmos. Chem. Phys., 15, 10999-11009, doi:10.5194/acp-15-10999-2015, 2015.

Müller, M., Neuber, R., Fierli, F., Hauchecorne, A., Vömel, H., and Oltmans, S. J.: Stratospheric water vapour as tracer for Vortex filamentation in the Arctic winter 2002/2003, Atmos. Chem. Phys., 3, 1991-1997, doi:10.5194/acp-3-1991-2003, 2003.

Network for the Detection of Atmospheric Composition Change (NDACC): Stratospheric ozone profiles, available at: http://www. ndacc.org/, last access: 1 February 2017.

Offermann, D., Grossmann, K.-U., Barthol, P., Knieling, P., Riese, M., and Trant, R.: Cryogenic Infrared Spectrometers and Telescopes for the Atmosphere (CRISTA) experiment and middle atmosphere variability, J. Geophys. Res.-Atmos., 104, 1631116325, doi:10.1029/1998JD100047, 1999.

Peter, R.: The ground-based millimeter-wave ozone spectrometer GROMOS, IAP Research Report 97-13, Institut für angewandte Physik, Universität Bern, Bern, Switzerland, 1997.

Polvani, L. M. and Saravanan, R.: The Three-Dimensional Structure of Breaking Rossby Waves in the Polar Wintertime Stratosphere, J. Atmos. Sci., 57, 3663-3685, doi:10.1175/15200469(2000)057<3663:TTDSOB>2.0.CO;2, 2000.

Randel, W. J., Gille, J. C., Roche, A. E., Kumer, J. B., Mergenthaler, J. L., Waters, J. W., Fishbein, E. F., and Lahoz, W. A.: Stratospheric transport from the tropics to middle latitudes by planetary-wave mixing, Nature, 365, 533-535, doi:10.1038/365533a0, 1993.

Rienecker, M., Suarez, M., Todling, R., Bacmeister, J., Takacs, L., Liu, H.-C., Gu, W., Sienkiewicz, M., Koster, R., Gelaro, R., Stajner, I., and Nielsen, J.: The GEOS-5 Data Assimilation System - Documentation of Versions 5.0.1, 5.1.0, and 5.2.0, Tech. Rep. NASA/TM-2007-104606, vol. 27, NASA GSFC, 2008.

Schwartz, M. J., Lambert, A., Manney, G. L., Read, W. G., Livesey, N. J., Froidevaux, L., Ao, C. O., Bernath, P. F., Boone, C. D., Cofield, R. E., Daffer, W. H., Drouin, B. J., Fetzer, E. J., Fuller, R. A., Jarnot, R. F., Jiang, J. H., Jiang, Y. B., Knosp, B. W., Krüger, K., Li, J.-L. F., Mlynczak, M. G., Pawson, S., Russell, J. M., Santee, M. L., Snyder, W. V., Stek, P. C., Thurstans, R. P., Tompkins, A. M., Wagner, P. A., Walker, K. A., Waters, J. W., and $\mathrm{Wu}, \mathrm{D}$. L.: Validation of the Aura Microwave Limb Sounder temperature and geopotential height measurements, J. Geophys. Res.-Atmos., 113, D15S11, doi:10.1029/2007JD008783, 2008.

Steinbrecht, W., Claude, H., Schönenborn, F., McDermid, I. S., Leblanc, T., Godin-Beekmann, S., Keckhut, P., Hauchecorne, A., Van Gijsel, J. A. E., Swart, D. P. J., Bodeker, G. E., Parrish, A., 
Boyd, I. S., Kämpfer, N., Hocke, K., Stolarski, R. S., Frith, S. M., Thomason, L. W., Remsberg, E. E., Von Savigny, C., Rozanov, A., and Burrows, J. P.: Ozone and temperature trends in the upper stratosphere at five stations of the Network for the Detection of Atmospheric Composition Change, Int. J. Remote Sens., 30, 3875-3886, doi:10.1080/01431160902821841, 2009.

Studer, S., Hocke, K., and Kämpfer, N.: Intraseasonal oscillations of stratospheric ozone above Switzerland, J. Atmos. Sol.-Terr. Phys., 74, 189-198, 2012.

Studer, S., Hocke, K., Schanz, A., Schmidt, H., and Kämpfer, N.: A climatology of the diurnal variations in stratospheric and mesospheric ozone over Bern, Switzerland, Atmos. Chem. Phys., 14, 5905-5919, doi:10.5194/acp-14-5905-2014, 2014.

Waters, J. W., Froidevaux, L., Harwood, R. S., Jarnot, R. F., Pickett, H. M., Read, W. G., Siegel, P. H., Cofield, R. E., Filipiak, M. J., Flower, D. A., Holden, J. R., Lau, G. K. K., Livesey, N. J., Manney, G. L., Pumphrey, H. C., Santee, M. L., Wu, D. L., Cuddy, D. T., Lay, R. R., Loo, M. S., Perun, V. S., Schwartz, M. J., Stek, P. C., Thurstans, R. P., Boyles, M. A., Chandra, K. M., Chavez, M. C., Chen, G. S., Chudasama, B. V., Dodge, R., Fuller, R. A., Girard, M. A., Jiang, J. H., Jiang, Y. B., Knosp, B. W., LaBelle, R. C., Lam, J. C., Lee, K. A., Miller, D., Oswald, J. E., Patel, N. C., Pukala, D. M., Quintero, O., Scaff, D. M., Van Snyder, W., Tope, M. C., Wagner, P. A., and Walch, M. J.: The Earth Observing System Microwave Limb Sounder (EOS MLS) on the Aura satellite, IEEE T. Geosci. Remote, 44, 1075-1092, 2006.
Waugh, D. W.: Seasonal variation of isentropic transport out of the tropical stratosphere, J. Geophys. Res.-Atmos., 101, 4007-4023, doi:10.1029/95JD03160, 1996.

Zülicke, C. and Peters, D. H. W.: Parameterization of Strong Stratospheric Inertia-Gravity Waves Forced by Poleward-Breaking Rossby Waves, Mon. Weather Rev., 136, 98-119, 2008. 